\title{
Framing the Epidemic: NGos and the Fight Against HIV/AIDS in Russia
}

\author{
Ulla Pape \\ Freie Universität Berlin \\ ulla.pape@fu-berlin.de
}

\begin{abstract}
With more than one million people living with HIV, Russia is facing the biggest HIV epidemic in Europe and is one of the few countries in the world where infection rates are increasing. The response to the epidemic is shaped by the way Russian state actors and non-governmental organizations (NGOS) view the issue of HIV and how they define policy priorities.

In order to understand the factors that underlie HIV policies in Russia, this contribution analyses the framing of HIV. It thereby makes use of framing theory. Based on document analysis and interviews with NGO experts, the article differentiates between four main framings in Russia: the framing of HIV as a medical issue, as a security threat, as a moral problem or as a human rights concern.

In Russia, the moral framing of HIV has become dominant over the past decade. The epidemic is increasingly viewed as the result of harmful influences from the West which need to be overcome. As a result, Russia has departed from evidencebased approaches to HIV. Instead, it solely focuses on strengthening so-called "traditional values", e.g. by engaging in healthy lifestyle promotion. The moral framing of HIV has also impacted the mobilization potential of Russian NGOs, as it favour those organizations that relate to the dominant framing of HIV and support government priorities.
\end{abstract}

\section{Keywords}

non-governmental organizations (NGOs) - civil society - framing - frames - HIV Russia - traditional values - moral approach 


\section{Introduction}

Nongovernmental organizations (NGOs) fulfill many important functions in society. In civil society research, their arena is commonly defined as the 'social space beyond the market, the state, and the household'. ${ }^{1}$ By providing fora for discussion and exchange, civil society allows citizens to come together, organize themselves and deal with topics of common concern and interest. The motivations of NGOs are various. They range from non-political club-type activities to political advocacy with the aim of changing public policies. Common to all NGOs is that they are based on a shared understanding of a meaningful and fulfilling activity that unites their members and supporters.

In democratic political systems, various channels of societal interest representation and mediation exist. Political parties play a prominent role in responding to public concerns, in defending the interests of different population groups, in formulating positions and in finding solutions in the political arena. Non-democratic or hybrid political systems are characterized by the fact that the forms of political interest representation and mediation are restricted. In countries such as Russia, political parties are largely stripped of their function of societal intermediates. They are not effective in responding to citizens' needs and achieving a common good. What does this mean for NGOs?

The context for NGOs operating in non-democratic or hybrid political regimes differs from that of democratic political regimes. The space for civil society is much less independent and autonomous than traditional, mostly Western-oriented, civil society theories suggest. As a result, NGOs cannot operate without restrictions and face different forms of state domination and/ or cooptation. ${ }^{2}$ However, the organizations also respond to the missing link between society and the state in these regimes and can make use of opportunities provided by the political context. ${ }^{3}$ Due to the limited functioning of political interest mediation, civil society actors remain one of the few intermediaries in society. Hence, in hybrid political regimes, civil society inevitably becomes more politicized than in democratic political regimes.

1 Lester M. Salamon and S. Wojciech Sokolowski, "Beyond Nonprofits: Re-conceptualizing the Third Sector". Voluntas: International Journal of Voluntary and Nonprofit Organizations 27, no 4 (2016): $1515^{-1545}$.

2 Yulia Skokova, Ulla Pape, and Irina Krasnopolskaya, "The Non-profit Sector in Today's Russia: Between Confrontation and Co-optation", Europe-Asia Studies 70, no 4 (2018): 531-563.

3 Elena Bogdanova, Linda Cook, and Meri Kulmala. "The Carrot or the Stick? Constraints and Opportunities of Russia's cso Policy”, Europe-Asia Studies 70, no 4 (2018): 501-513. 
This article studies how NGos deal with social policy issues. It analyzes how organizations define their goals and activities and create legitimacy for their work. The article builds upon empirical research on NGOs that are active in the field of HIV and Aids in Russia. In investigating the constraints and opportunities for these NGos, the article uses the concept of 'framing' to explain how these organizations define their goals and rationale for existence. Framing is a core concept in the study of social movements. ${ }^{4}$ It helps us to understand how groups and organizations describe their social cause and legitimize their activities. The framing process and civil society action are interlinked. First, NGOs and other civil society actors actively participate in the framing processes of social issues and thereby shape public discourses. Second, the frames themselves shape opportunities and constraints for civil society actors. Depending on the dominant frames in a given problem area, NG Os can to different degrees be able to justify their role and create societal support for their work. Moreover, NGOs can use framing to broaden their opportunities for defining policy priorities.

In the policy field of HIV/AIDS, framing is of particular importance, as it shapes the ways NGO activists and society view the issue of HIV and how they define policy priorities. In the analysis, the notion of framing is used to investigate how activists and organizations have presented the issue of HIV in Russia and how they have defined their own role in responding to the epidemic. The focus on action frames allows for a discussion of the factors that shape the constraints and opportunities for these organizations. The article is structured as follows: First, the article provides an analytical framework that will guide the investigation of framing HIV in Russia. Second, the organizational field of Russian NGOs in the field of HIV in Russia will be described. This overview will present a classification of different types of NGOs. Third, the four main frames of HIV will be discussed. The following discussion will focus on the questions how the different frames resonate in Russian society. In the conclusion, three main factors will be illustrated that directly relate to the failure of addressing the HIV/AIDS epidemic in Russia.

\section{Understanding the Framing of HIV in Russia}

The notion of 'frames' was first introduced by sociologist Erwin Goffman, who used the term to describe 'schemata of interpretation' that allow individuals or

4 Robert D. Benford and David A. Snow, "Framing Processes and Social Movements: An Overview and Assessment", Annual Review of Sociology 26, no. 1 (2000): 611-639. 
groups to organize, perceive and make sense of their experiences. ${ }^{5}$ According to Goffman, frames are inevitable for individuals to orientate themselves in the world. ${ }^{6}$ Frames thus shape the behavior of individuals and their interaction with others. The term 'frames' refers to the interpretation schemes as such, while 'framing' describes the process of constructing interpretations in human communication.

The concepts of 'frames' and 'framing' have been widely applied in many fields of the social sciences and became particularly relevant for understanding the dynamics of political communication and social movements. Robert M. Entman introduced the concepts to communication analysis. ${ }^{7} \mathrm{He}$ described how political issues are constructed and presented in the media. According to Entman, framing involves the selection and highlighting of information in order 'to construct an argument about problems and their causation, evaluation and/or solution'. ${ }^{8}$ Entman suggested a convincing concept for analyzing framing that consists of four elements: (1) problem definition, (2) causal interpretation, (3) moral evaluation and (4) treatment recommendations. ${ }^{9}$

The notion of framing has also gained widespread currency in the research on social movements and civil society organizations. Benford and Snow have shown how framing relates to the dynamics of collective action..$^{10}$ Social movements make use of collective action frames 'to mobilize potential adherents and constituents, to garner bystander support and to demobilize antagonists.'11 In the definition of Robert Benford and David Snow, frames are 'action-oriented sets of beliefs and meanings that inspire and legitimate the activities and campaigns of a social movement organization.'12 According to Benford and Snow, movements and groups are successful, if they are able to create convincing frames that are supported by as many possible participants and encourage them to take action. ${ }^{13}$

Erving Goffman, Frame Analysis: An Essay on the Organisation of Experience (New York: Harper \& Row, 1974).

$6 \quad$ Ibid.

7 Robert M. Entman, "Framing: Toward Clarification of a Fractured Paradigm", Journal of Communication 43, no 4 (1993): 51-58.

$8 \quad$ Ibid, 53 .

9 Ibid, $5^{2}$.

10 Benford and Snow have published several articles on the link between framing and collective action. The most relevant article here is "Framing Processes and Social Movements".

11 David A. Snow and Robert D. Benford, "Ideology, frame resonance, and participant mobilization”, International Social Movement Research 1, no 1 (1988): 197-217, here: 198.

12 Benford and Snow, "Framing Processes and Social Movements", 614.

13 Ibid. 
Previous studies on framing in civil society have examined how civil society organizations have used framing to create societal support and influence public policy, both at the local, national or international levels. ${ }^{14}$ Framing is of particular importance with regard to the advocacy function of civil society organizations. Organizations attempt to influence public policy by 'framing problems, solutions and justifications for political action'. ${ }^{15}$ Transnational advocacy networks play an important role in framing processes, as they create international communities that construct and share joint action frames, which enables organizations to assert pressure on political decision-makers across borders. ${ }^{16}$

In this analysis on the framing of HIV/AIDS in Russia, the notions of frames and framing are used to investigate the way activists and organizations understand the issue of HIV/AIDS in Russia. How do they view the issue of HIV/AIDS and how do they define their own role in responding to the epidemic? The situation in Russia is characterized by the fact that there is no consensus on what the epidemic means for society and what should be done about it. The response to the epidemic is subject to a controversial debate in Russian society. Individual activists and organizations are divided in their understanding of the issue. While some view the epidemic as an exclusively medical issue which calls for purely medical interventions, others understand it as a social problem which requires a broader rights-based response, which should also include the overcoming of stigma and marginalization of vulnerable groups which are the most affected by HIV in Russia. Still other societal groups regard the epidemic primarily as a problem of morality, which is to be overcome by a change of attitudes.

These different framings of the epidemic also affect the way activists and NGOs view their own role in the response to HIV/AIDS in Russia. While some see themselves and their organizations as responsible for implementing programs that assist the state in the provision of social services, others take a more critical stance and define themselves as activists defending the rights of marginalized groups. Also, with regard to national HIV/AIDs policies, Russian activists and NGOs hold different views: While some argue that Russia should

14 For studies on nonprofit framing see for instance Jutta Joachim, "Framing Issues and Seizing Opportunities: The Un, NGOs, and Women's Rights”, International Studies Quarterly 47 (2003): 247-274, and Katerina Tsetsura, "Challenges in Framing Women's Rights as Human Rights at the Domestic Level: A Case study of NGOs in the Post-Soviet countries", Public Relations Review 39, no 4 (2013): 406-416.

15 Joachim, "Framing Issues and Seizing Opportunities", 247.

16 Margaret E. Keck and Kathryn Sikkink, Activists beyond Borders: Advocacy Networks in International Politics (Ithaca, Cornell University Press, 1998). 
follow international experience and evidence-based approaches endorsed by UNAIDS and other international organizations, others argue that Russia should find its own way in dealing with the epidemic by strengthening traditional values. How NGOs and other social actors frame the issue of HIV/AIDS affects the way they can act and the opportunities they have to influence HIV/AIDS policies in Russia.

To understand the role of civil society in the response to HIV/AIDS in Russia, two guiding questions will therefore be posed:(1) How is the issue of HIV/AIDs framed in Russia, and (2) How do different actors define their role in the response to the epidemic? The analysis builds upon the framework of Entman, which offers an overview of the main dimensions of framing, and the concept of strategic action frames, developed by Benford and Snow, who have shown how framing relates to organizational strategies.

\section{3}

The Organizational Field of HIV/AIDS NGOs in Russia

Before turning to the framing of HIV in Russia, it is necessary to provide an overview of the organizational landscape of NGOs that are active in the field of HIV and Aids in Russia. The organizations differ in terms of their history, motivation, objectives and interaction with state institutions and society. A classification based on NGO behavior is therefore essential for understanding the differences between the organizations and their link to the framing of HIV in Russia.

At the local level, one can distinguish between grassroots NGOs and government affiliates. According to Cook and Vinogradova, grassroots NGOs are active at the community level and address the needs of specific social groups. ${ }^{17}$ The functions of grassroots NGOs in the field of HIV/AIDS range from mutual aid to the defense of social rights. An important element of their work is the provision of social services, e.g. HIV/AIDS prevention programs for vulnerable groups, needle exchange services and information campaigns. ${ }^{18}$ Grassroots NGOS often assist their members or clients on an individual basis by helping them to solve everyday problems and assert their rights vis-à-vis bureaucratic state services. External funding and countrywide HIV/AIDS programs such as the GLOBUS project allowed grassroots NGOS to develop their organizational capacities and grow into professional service providers. At the local and

\footnotetext{
17 Linda J. Cook and Elena Vinogradova, "NGOs and Social Policy-Making in Russia's Regions", Problems of Post-Communism 53, no. 5 (2006): 28-41, here: 31.

18 Interview with NGO representative, Kaliningrad, 14 October 2008.
} 
regional levels, many NGOs closely collaborate with state institutions, mostly in the health care and educational sector. ${ }^{19}$ In many regions of Russia, grassroots NGOs were among the first to set up programs for HIV prevention and psychosocial assistance. ${ }^{20}$ A specific sub-group of grassroots NGOs are selfhelp initiatives, which aim to provide mutual assistance in overcoming stigma and social exclusion. Often, self-help initiatives deal with practical issues such as access to antiretroviral therapy, treatment adherence or drug rehabilitation. Some self-help initiatives provide legal advice and support to their members. $^{21}$

Many grassroots NGOs in Russia emphasize that they have grown from social initiatives and rest on the commitment of people 'who understand and who care.'22 The particular strength of grassroots organizations in the HIV/AIDS sector lies in their direct contact with the communities they are dealing with, which often belong to the most marginalized groups of Russian society. Another advantage of grassroots NGOs is their innovative potential: through cooperation with state institutions they have introduced new approaches into Russian HIV/AIDs policies. These new approaches include, for instance, peer-to-peer counselling, outreach work or case management, which have all been unfamiliar in Russia and were first introduced through the work of NGOs. Through adopting these social work techniques in the field of HIV/AIDS, grassroots NGOs have proven their applicability and use in practice and thereby changed the response to Russia's HIV/AIDS epidemic from the bottom-up.

The second group of local HIV/AIDS organizations - government affiliates is characterized by their strong link with state authorities. As a rule, government affiliates or "marionette" NGOs do not function as independent civil society organizations, but rather fulfil the demands of their overarching state structures. ${ }^{23}$ Often, civil servants created additional NGOs in order to expand their services and channel extra-budgetary funds. ${ }^{24}$ In many cases, medical doctors working for regional AIDS centers established NGOs to organize additional activities that could not be realized on the basis of the government institution itself. ${ }^{25}$ Budgetary cuts in the governmental health care system

\footnotetext{
19 Interview with NGO representative, Tomsk, 21 December 2007.

20 Ibid.

21 Interview with NGO representative, St. Petersburg, 6 October 2008.

22 Interview with NGO representative, Tomsk, 21 December 2007.

23 Cook and Vinogradova, "NGos and Social Policy-Making in Russia's Regions", 34-35.

24 Ibid, here: 38 .

25 Interview with NGO representative, Tomsk, 17 January 2008.
} 
meant that many medical doctors decided to establish an NGO alongside their medical institution. This allowed them, for instance, to conduct HIV/AIDS prevention activities for which there was no funding at the institution. ${ }^{26}$

The legitimacy of government-affiliated NGOS in the fight against HIV/AIDS in Russia is subject to controversial debate. While the organizations themselves defend their work with a reference to the need of professional services that they are able to provide, ${ }^{27}$ critics argue that Russian AIDs centers simply aimed to attract additional funds for their regular work. ${ }^{28}$ Government affiliates are often labelled 'pocket organizations', a term that suggests that the NGOs have not been established in accordance with their officially stated charitable mission, but rather as a resource of the state institutions. ${ }^{29}$

At the national level, we can distinguish between three groups of HIV/AIDS NGOs: (1) policy/advocacy NGOs, (2) government affiliates, and (3) NGO networks. In contrast to local NGOS, all of these large, Moscow-based NGOs have access to international organizations, transnational NGO networks and/or political decision-makers in Russia. Moreover, the big players in the Russian HIV/AIDS sector have a substantially higher budget and more paid staff members than their regional counterparts. They are also seen as being more professionalized in terms of modern NGO management standards than local NGOs. ${ }^{30}$

The first group - policy/advocacy NGOS - includes those organizations that manage countrywide programs in the field of HIV/AIDS. The best-known is the GLOBUS project, which is led by a consortium of five Russian and international NGOs: the Open Health Institute (OHI), AIDS Foundation East-west (AFEW), Population Services International (PSI), Focus-Media and Aids Infoshare. The GLOBUS project 'aims to stimulate an effective national strategy to counteract the HIV/AIDS epidemic in Russia.. ${ }^{31}$ It was started in 2004 as the first HIV/AIDS program funded by the Global Fund (GFATM) in Russia. The GLOBUS project combines the implementation of HIV/AIDS prevention activities with advocacy work, thereby striving to inform the Russian public about HIV/AIDS and convince Russian decision-makers to adopt effective strategies in the fight against the epidemic. ${ }^{32}$

\footnotetext{
26 Ibid.

27 Ibid.

28 Interview with NGO representative, Kaliningrad, 16 October 2008.

29 Interview with NGO representative, St. Petersburg, 20 May 2008; and interview with NGO representative, Kaliningrad, 16 October 2008.

30 Interview with NGO representative, Moscow, 5 February 2007.

31 "GLOBUS Project. Information Newsletter", no. 1 (3) (2006): 3.

32 Ibid, 14.
} 
Policy/advocacy N GOs are highly professionalized organizations. They focus on the formulation and implementation of policy and defending the interests of those social groups that are most affected by HIV/AIDS in Russia. ${ }^{33}$ In contrast to local NGOs, their programs aim to cover the entire country, or at least a significant number of project regions. In the implementation of nationwide HIV/AIDS programs, policy/advocacy NGOs cooperate with regional partner organizations, be it grassroots NGOs or government affiliates. Many of the central policy/advocacy NGOs came into being with the aid of foreign assistance and have close contacts with transnational networks and international organizations.

An important component in the work of policy/advocacy NGOs in Russia is information gathering and exchange. Through research projects and the organization of conferences, media campaigns and information websites, the NGOs strive to raise public awareness and promote policy changes in an effort to improve Russia's response to the HIV/AIDS epidemic. Another forum for information exchange is the workshops and joint projects that are organized to strengthen the organizational capacity of local NGOs. Common to all policy/advocacy NGOs is that they strive to improve Russian HIV/AIDS policies at large. The experience of other countries in the fight against the epidemic as well as (international) research findings on prevention strategies and their effectiveness - so-called evidence-based approaches - thereby function as guidelines for their recommendations to Russian decision-makers. Overall, the NGOs largely follow the policy positions of UN agencies, e.g. UNAIDS and UNODC, and advocate for a Russian response to the epidemic which is in line with international evidence and requirements. ${ }^{34}$

The second group of HIV/AIDS NGOs, working at the federal level, are government affiliates. Similarly, to their regional counterparts, they have been established with the support of state institutions and can therefore be regarded as quasi-NGOs. One of the best-known organizations of this kind is the Russian Health Care Foundation, which was founded in 1996 in accordance with a decree passed by the Russian government. ${ }^{35}$ The organization was established as an NGO with the explicitly formulated goal of assisting in the 'implementation of programs and projects funded by international financial organizations and foreign governments for Russia:. ${ }^{36}$ Since 2005, the Russian Health Care

33 This characterization of policy/advocacy NGOs follows the definition by Cook and Vinogradova, "NGos and Social Policy-Making in Russia's Regions", 31.

34 Interview with NGO representative, Moscow, 22 May 2008.

35 Russian Health Care Foundation, available at http://www.srhiv.mednet.ru/open/fund .php, accessed at 17 June 2018. Ibid. 
Foundation has been implementing a program on HIV/AIDS prevention, treatment, care and support, which as of 2010 is the largest program funded by the GFATM in Russia. ${ }^{37}$

The third category of organization refers to NGO networks. One example is the Russian Association of People Living with HIV, which aims to defend the rights of PLWH in Russia, particularly in terms of access to antiretroviral therapy and other medical services. ${ }^{38} \mathrm{An}$ important element of the association is the information exchange with local PLWH groups, which allows the network to monitor access to treatment throughout the country. The organization is therefore able to hold the institutions accountable if promised services are not delivered. This is particularly relevant with regard to the frequent disruption in the supply of ARv's in Russia's region. The International Treatment Preparedness Coalition (IтPCru) follows a similar objective. The coalition was set up in 2006 by activists to improve information exchange on access to treatment and human rights protection. ${ }^{39}$ Since then, the website and mailing list of IтPCru have developed into a popular communication tool of the PLWH community in the region of Eastern Europe and Central Asia.

Other examples of NGO networks in the field of HIV/AIDS are the National Forum of AIDS-service NGOS in Russia, established in order to strengthen the role of NGOS in the fight against Russia's HIV/AIDS epidemic, and the Russian Harm Reduction Network, which combines support of local needle exchange projects with advocacy work at the regional and federal levels. NGO networks in Russia have received substantial support from international organizations, which have promoted the idea of networking in an effort to enhance the capacities of Russian HIV/AIDS NGOs. UNAIDS, for example, assisted the creation of the Russian Association of People Living with HIV and the National Forum of AIDS-service NGOs in Russia. ${ }^{40}$ The Russian Harm Reduction Network, on the other hand, received a grant from the Global Fund in order to implement needle exchange projects in Russia.

Crucial to the work of NGO networks is the exchange of information and experience. This enables local organizations and activists to communicate their concerns about treatment disruptions and other questions and thereby

37 The Global Fund to Fight AIDs, Tuberculosis and Malaria, available at https://www.the globalfund.org/en/, accessed 5 July 2018.

38 Russian Association of People Living with HIV, http://www.positivenet.ru/, accessed 5 July 2018.

39 The International Treatment Preparedness Coalition (IтPCru), http://itpcru.org/en/ itpcru/, accessed 1 October 2018.

40 Russian Association of People Living with HIv, http://www.positivenet.ru/, accessed 5 July 2018. 
exert pressure on the responsible state institutions. In addition, the exchange of information allows local activists to gain knowledge on certain issues and use their mobilization potential. Another advantage of network organization rests on their combination of service delivery and advocacy, which enables the NGOs to formulate policy proposals on the basis of practical evidence. This aspect is particularly evident in the work of the Russian Harm Reduction Network, which aims to promote the idea of harm reduction in Russia by implementing successful needle exchange projects throughout the country. In addition to their practical function, the needle exchange projects thus also serve as evidence for the applicability and usefulness of this approach in the response to HIV/AIDS in Russia.

The overview of the organizational landscape of HIV/AIDS NGOs in Russia shows that the organizations display different forms of interaction with state and society. NGOs primarily orient themselves on the 'logic of appropriateness' of the resource providers they mainly depend on, be it foreign organizations, Russian state institutions or local communities. ${ }^{41}$ However, the divisions between funding sources are less clear cut than one might expect at the first glance. Many NGOs receive funding from different sources, thereby relying on external donors, state subsidies and private donations. ${ }^{42}$ This means that the NGOs need to balance different demands. They not only need to take into account the expectations of their donors, but also those of their cooperation partners, members and local constituencies.

\section{Framing HIV in Russia}

When analyzing the framing of HIV in Russia, four main frames can be identified. The first is the framing of HIV as a medical issue. The main actors in this medical discourse are the Ministry of Health and the Federal Aids Center, which is part of the state organization Rozpotrebnadzor. The Federal AIDS Center is in charge of the epidemiological surveillance of HIV infection as well as prevention, clinical diagnosis and medical care. ${ }^{43}$ It consists of a network of seven interregional AIDS centers in the federal districts, 83 regional AIDS centers in the regions, and more than 20 municipal AIDS centers. ${ }^{44}$ The

41 Laura A. Henry, "Shaping Social Activism in Post-Soviet Russia: Leadership, Organizational Diversity, and Innovation", Post-Soviet Affairs 22, no. 2 (2006): 99-124, here: 103.

42 Interview with NGO representative, Tomsk, 21 December 2007.

43 Federal Aids Center, http://www.hivrussia.ru/ (accessed 27 June 2018).

44 Since 2014, the Federal Aids Center also has a branch on Crimea. 
center collects epidemiological data from its regional subdivisions and monitors the overall epidemiological development of HIV in Russia. ${ }^{45}$ In 2004, the Federal AIDs Center was integrated into the newly established Federal Service for Surveillance on Consumer Rights Protection and Human Well-being (Rospotrebnadzor). ${ }^{46}$ The director of the Federal Aids Center, Vadim Pokrovskii, is the most visible state representative in the medical discourse on HIV/AIDS in Russia. ${ }^{47}$

The strength of the medical frame is the focus on epidemiological data. Pokrovskii's main message is that the epidemiological situation in Russia is deteriorating. On AIDs Memorial Day in May 2018, he declared that "HIV has moved beyond vulnerable groups and is actively spreading in the general population". ${ }^{8}$ Pokrovskii continued his speech with the statement that "[t]he number of new cases is increasing, the coverage of treatment cannot keep up with the number of new infections, as the number of new cases increases, which means that preventive measures are ineffective, mortality increases and treatment is ineffective". 49

Based on Entman's model on framing, one can observe that the medical frame centers on the problem definition ("the epidemic") and the causal explanations ("the factors that enable the increasing spread of HIV in Russia"). The weakness of the medical frame is that it does not address the broader societal context and, even more importantly, does not offer any policy solutions. As a result, the medical frame remains restricted to the explanation of the epidemiological trends of HIV infection. This is reinforced by the fact that Pokrovskii as a medical doctor has a weak position and seems to lack a network among higher-ranking political decision-makers. His statements are frequently disputed by the federal Ministry of Health, which follows a far less critical line in describing the HIV situation in Russia. In contrast to the Federal AIDS Center, the Ministry of Health avoids the term "epidemic" and is very cautious with highlighting the worsening of the HIV situation in Russia. ${ }^{50}$ Pokrovskii's warnings therefore often appear to be a lone voice in the wilderness.

\footnotetext{
45 Federal Aids Center, http://www.hivrussia.ru/ (accessed 27 June 2018).

46 Ibid.

47 Ibid.

48 Valeriia Mishina, “Bolee $1 \%$ vzroslogo naseleniia Rossii zhivut s VICh”, Komersant, 23 May 2018, https://www.kommersant.ru/doc/3637277, accessed 5 July 2018.

49 Ibid.

5o In the State Strategy, the word "epidemic" does not appear; State Strategy to Confront the Spread of HIV in Russia until 2010, Decree 2203, 20 October 2016, http:/government.ru/ docs $/ 24983 /$, accessed 27 of June 2018.
} 
Within civil society, the framing of HIV as a medical issue is followed by many local organizations that have been established on the basis of the regional AIDS centers. Both grassroots NGOS and government affiliates use the medical frame to describe their activities and legitimize their work as service providers. The NGOs provide a plethora of medical information on their websites and in the form of leaflets and other printed information. The majority of this information is of a practical nature. It describes what patients need to know about treatment and prevention and includes information for the general population. As a rule, the information provided by NGOs on their websites, is accurate and useful. One example is the website of the Tomsk NGO Siberian Aids Help, which comprises background information on HIV infection and prevention, organizational characteristics, activities, programs, news, and funding opportunities. ${ }^{51}$ In placing information on their websites, the NGOs also emphasize their relevance as providers of medical and psychosocial services. The medical frame thus enables them to stress the reasons why they are important.

The second frame that can be identified in Russia is the frame of HIV as a security threat. This frame was most prominently voiced in President Putin's address to the National Security Council in 2006. On 21 April, Putin called for an assembly of the Presidium of the State Council, an advisory body to the Russian Head of State that is assigned to deal with issues of highest importance to the state as a whole. On the top of the agenda was the growing HIV/AIDS epidemic in Russia and its potential security implications. In his opening speech, Putin voiced his deep concern about the ongoing spread of HIV infection among the Russian population. He particularly emphasized its negative impact on the country's demographic situation and called for a comprehensive national response strategy: "This is a serious situation that requires us to take the appropriate action. We need more than words; we need action, and the whole of Russian society must get involved". 52

According to Sjöstedt, the president's speech can be regarded a securitization move, as Putin for the first time publicly declared HIV/AIDs to be a threat to Russia's national security. ${ }^{53}$ Putin's speech led to a number of important

\footnotetext{
51 Siberian AIDSAid, http://www.aids.tomsk.ru/, accessed 2 July 2018.

52 Vladimir Putin, "Vstupitel'noe slovo na zasedanii prezidiuma Gosudarstvennogo soveta 'O neotlozhnykh merakh po bor'be s rasprostraneniem vich-infektsii v Rossiiskoi Federatsii', 21 aprelia 2006 goda", 21 April 2006, http://kremlin.ru/events/president/tran scripts/23547, accessed 4 July 2018.

53 Roxanna Sjöstedt, "Exploring the Construction of Threats: The Securitization of HIV/AIDS in Russia", Security Dialogue 39, no. 1 (2008): 7-29.
} 
policy changes in the same year. The Russian State Duma held hearings on the problem of HIV/AIDS and its impact on Russian society. Moreover, the fight against HIV/AIDS and other infectious diseases was declared a priority issue for the G8 summit in St. Petersburg that took place in June 2006. Russia's National Security Strategy, approved in May 2009, also identifies HIV-infection and a number of other health problems as factors that increase mortality and thus endanger Russia's national security. ${ }^{54}$ Even more importantly, a government commission was established in order to deal with HIV/AIDS, and state funding was substantially increased for the following years. ${ }^{55}$ UNAIDs representative Lindblad therefore called Putin's speech a 'milestone in the fight against HIV/AIDS in Russia., 56

The strengths of the security frame lies in its appellative character ("we need action, and the whole of Russian society must get involved"). The frame signaled that the epidemic had become an issue of the highest political concern in Russia. NGOs were not involved in the securitization of HIV, as security politics traditionally is a policy area reserved for high-ranking decision-makers. However, the prioritization of the epidemic as a security threat opened up new opportunities for Russian and international NGOs. At the G8-summit, for example, the Russian government emphasized its partnerships with NGOs in its response to the epidemic. ${ }^{57}$ Moreover, the government pledged to provide future funding for NGO programs in the field of HIV, most notably for the Globus program, which was conducted by a consortium of five Russian and foreign NGOs. For the organizations, the growing awareness among Russian decisionmakers meant that their work was seen as important.

The weakness of the security frame, however, is that it does not include any policy recommendations. In his speech, Putin called for intensifying the efforts

54 Russian Security Council "Strategy of National Security of the Russian Federation until 2020, confirmed by Decree of the President of the Russian Federation No 537 of 12 May 2009," as published in Krasnaia Zvezda, weekly edition 20-26 May 2009, accessed 15 June 2018.

55 Alexey Bobrik and Judyth L. Twigg. "HIV/AIDS in Russia”, in Judyth L. Twigg ed., HIV/AIDS in Russia and Eurasia (New York: Palgrave Macmillan, 2006): 1-40.

56 UnAids, "President Putin Calls for Urgent Measures to Stem the HIV Epidemic in Russia”, 26 April 2006, http://www.unaids.org/en/resources/presscentre/featurestories/2006/ april/20060426russia, accessed 1 July 2018.

57 J. Stephen Morrison and Jennifer Kates, "The G-8, Russia's Presidency, and HIV/AIDs in Eurasia: A Report of the csis Task Force on HIV/AIDS in collaboration with the Kaiser Family Foundation", Washington, D.C.: Kaiser Family Foundation, 14 June 2006, https:// kaiserfamilyfoundation.files.wordpress.com/2013/04/csisg8russpres.pdf, accessed 22 June 2018. 
to combat HIV but did not formulate any concrete steps in this direction. Furthermore, the framing of HIV as a security threat was dominant only for a short time. One can argue that it lasted from 2006, when Putin gave his speech on HIV, to 2008, when Russia started to move gradually away from international approaches to HIV prevention and treatment. With the military conflict in Georgia in August 2008 and the subsequent exclusion of Russia from the G8, Russia's growing conflict with the West became evident. Although these international developments were not related to health policies, Russia's response to the HIV epidemic became entangled with the increasing tensions with the West. Russia's reorientation in foreign policy also led it to reject evidencebased prevention approaches endorsed by international health organizations. An important subject in this controversy is harm reduction programs, which international organizations regard as effective for reducing the incidence of HIV in people who inject drugs. The Russian government does not support harm reduction on a broad scale and instead focuses on the promotion of healthy lifestyles among the general population. International observers have criticized Russia's approach as 'incomprehensibly short-sighted. ${ }^{58}$

This conflict over the right approach to prevention gave rise to a third framing, the framing of HIV as an issue of morality. This link between the epidemic and morality is inherent to the issue. Due to its character as an 'acquired syndrome', HIV has always been accompanied by a debate about moral behavior. From its beginnings, the epidemic has been associated with promiscuous lifestyles' or other harmful or risky behavior such as drug use. As a rule, prevention programs focus on behavior change, which presupposes that they divide between 'good' and 'bad' behavior. An important societal player in shaping the discourse on HIV and morality is the Russian Orthodox Church. In 2004, the Holy Synod of the Russian Orthodox Church adopted the "Concept of the Russian Orthodox Church's Participation in Overcoming the Spread of HIV/AIDS and the Work with People Living with HIV/AIDs", which serves as a guideline for the ROC's approach to HIV/AIDS. ${ }^{59}$ In the document, the church described HIV as "one of the most serious threats to the cIs countries" and assured its participation in efforts to overcome the epidemic. ${ }^{60}$

58 "Editorial: The Future of Harm Reduction Programmes in Russia," The Lancet 374, no. 9697 (2009): 1213 .

59 "Kontseptsiia uchastiia Russkoi Pravoslavnoi Tserkvi v bor'be s rasprostraneniem vich/ SPIDa i rabote s liud'mi, zhivushchimi s vich/spidom," 24 June 2005, https://mospat .ru/ru/documents/koncepciya-uchastiya-russkojj-pravoslavnojj-cerkvi-v-borbe-s-raspros traneniem-vichspida-i-rabote-s-lyudmi-zhivushhimi-s-vichspidom/, accessed 1 July 2018. Ibid. 
An analysis of the concept shows that the Russian Orthodox Church frames HIV as an issue of morality. ${ }^{61}$ According to the church, the root causes for Russia's epidemic are to be seen in 'the abundance of sin and lawlessness as well as the loss of fundamental spiritual values, moral foundations and orientation in [Russian] society' ${ }^{62}$ In opposition to secular NGOs and the state, the church therefore sees its duty in a 'spiritual and moral appraisal of the HIV/AIDS epidemic'.63 Only this approach will enable Russia to overcome its current moral crisis. The church has an important role to play in the response to the epidemic, since it has the 'opportunity to offer a real and rescuing alternative to the widespread vice of today, including drug use, amorality and lack of spirituality'.64

With the growing influence of the church in Russian domestic politics, the moral framing of HIV has gained widespread currency. In common public discourse, it is linked to the strengthening of so-called 'traditional values', which are described by the church as something fundamentally different from the values of the West. In this moral framing, HIV is thus constructed as the result of immoral behavior that had been brought to Russia through harmful Western influence. To overcome the epidemic Russia therefore needs to overcome this influence and instead strengthen its own 'traditional values'. One can understand the moral framing thus as an ideational redefinition of Russia. In 2013, the reference to 'traditional values' was taken up by president Putin in his annual address to the Federal Assembly. ${ }^{65}$ In that speech Putin declared that 'traditional values' were threatened 'from above' and he saw Russia in the role of protecting these values globally: 'We know that there are more and more people in the world, who support our position of protecting of traditional values' ${ }^{\prime 6}$ From the context of the speech, it is clear that Putin understands 'traditional values' as opposed to international human rights norms, which in his view are imposed by the West. ${ }^{67}$

61 Jarrett Zigon "Morality and HIV/AIDs: A Comparison of Russian Orthodox Church and Secular NGo Approaches", Religion, State \& Society 37, no. 3 (2009): 317-318.

62 "Kontseptsiia uchastiia Russkoi Pravoslavnoi Tserkvi v bor'be s rasprostraneniem".

63 Ibid.

64 "V Moskve sostoialas' presentatsiia Kontseptsii uchatiia Russkoi Pravoslavnoi Tserkvi v bor'be s rasprostraneniem vich/sPIDa i rabote s liud'mi, zhivushchimi s vich/sPIDom," 6 September 2005, accessed 8 August 2018.

65 Poslanie Presidenta Federal'nomu Sobraniiu, 12 December 2013, http://kremlin.ru/events/ president/news/19825, accessed 1 October 2018.

66 Ibid.

67 Cai Wilkinson, "Putting 'Traditional Values' Into Practice: The Rise and Contestation of Anti-Homopropaganda Laws in Russia", Journal of Human Rights, no. 3 (2014): 363-379. 
Translated into the field of health care, the protection of 'traditional values' also includes the promotion of so-called 'healthy lifestyles'. Since 2009, the Russian government has been investing in 'healthy lifestyle promotion', ranging from anti-drug-use and anti-alcohol campaigns and programs advocating physical activity and sports. ${ }^{68}$ The framing of HIV thus also has very practical implications. Critical observers argue, however, that in the field of HIV, Russia's focus on healthy lifestyle promotion comes at the expense of preventis for vulnerable populations. Within civil society, many organizations have adopted the moral framing of HIV and the related discourse on healthy lifestyle promotion. There are different governmental programs that allow NGOs to apply for funding to set up programs for healthy lifestyle promotion, which can include information on HIV. ${ }^{69}$

The fourth framing of HIV in Russia is the framing of HIV as a human rights issue. This frame is supported by UNAIDs and other international health organizations as well as policy/advocacy NGOs in Russia. UNAIDS emphasizes the importance of human rights protection in the response to the epidemic. The organization states that '[a] human rights-based approach is essential to ending AIDS as a public health threat. Rights-based approaches create an enabling environment for successful HIV responses and affirm the dignity of people living with, or vulnerable to, HIV'.70 UNAIDS regularly organizes meeting and events that emphasize the need to protect the human rights of those, most affected by the epidemic. ${ }^{71}$ In 2016, UN experts warned that 'the AIDS epidemic is still driven by human rights violations around the world, including discrimination, violence, punitive laws, policies and practices.72

Within Russian civil society, the human rights frame is very productive, as it allows NGOs and groups to empower communities. For people living with

68 Alexander Gorobets, "Promotion of Sports, Physical Activity, and a Healthy Lifestyle in Russia", The Lancet 385, no. 9986 (2015): 2459.

69 In 2017, the Ministry of Health introduced a new funding programmes for healthy lifestyle promotion, Valeria Mishina, "Zdorovyj obraz zhizni podderzhat na kokursnoi osnove", Kommersant, 8 November 2017, https://www.kommersant.ru/doc/3460594, accessed 1 October 2017.

70 unAIDs (n.d.), Topic: Human rights, http://www.unaids.org/en/topic/rights accessed 12 June 2017.

71 UNAIDs, "Pravo na zdorov'e, pravo na zhizn': VICh i pravo cheloveka v Evrope", 29 May 2013, http://www.unaids.org/ru/resources/presscentre/featurestories/2013/may/201305 29euhiv, accessed 1 October 2018.

72 OHCHR, "AIDs epidemic still being driven by human rights violations" - UN experts warn", 3 June 2016, https://www.ohchr.org/RU/NewsEvents/Pages/DisplayNews.aspx?NewsID= 20055\&LangID=E, accessed 1 October 2018. 
HIV as well as vulnerable populations the acknowledgement of human rights is a central feature that defines the very purpose of groups and organizations. Many NGOs have adopted the human rights discourse, with the access to lifesaving antiretroviral treatment in particular framed as a human right. Moreover, many organizations offer legal advice for people living with HIV, such as the Russian NGO 'Positive Wave', which documents all legal regulations that protect the rights of people living with HIV in Russia. ${ }^{73}$

The strength of the human rights frame is its link to the international level. Russian NGOs and other societal actors can refer to international norms such as the Universal Declaration of Human Rights to substantiate their claims in regard to HIV policies. Moreover, this frame allows networking through community groups, as the right-based approach empowers vulnerable groups. However, overall the framing of HIV as a human rights issue remains weak in Russia as influential government actors oppose it. In official discourse, human rights are frequently portrayed as alien and imposed on Russia by foreign powers. In the official discourse on HIV in Russia, this position is therefore marginalized.

\section{$5 \quad$ Which Frames are Successful and Why?}

Benford and Snow describe the framing process as 'the struggle over the production of mobilizing and countermobilizing ideas and meaning. ${ }^{74}$ The response to HIV in Russia constitutes a policy field where opposing views are formulated and held against each other. Different policy actors, including the state and civil society, have developed diverging views on the course of the epidemic, its underlying causes and the most appropriate ways to combat it. The ways in which the epidemic is defined and negotiated in public discourses have an important impact on the policies and practices that are put forward by different policy actors. It is therefore important to understand the framing processes which lie at the heart of the struggle over ideas and meaning.

On the basis of media discourses and public communication on HIV one can identify four main frames that have shaped the response to the epidemic in Russia. The struggle over ideas and meaning refers both to the construction of the problem at stake ('how can one make sense of HIV?', 'why is the epidemic spreading in Russia?') and the proposed remedies ('what should be done

73 Positive Wave, https://pozvolna.ru/allrights/humanrights/2/, accessed 13 July 2018.

74 Benford and Snow, "Framing and Social Movements", 613. 
to combat HIV?', 'what are the roles of different actors - state and NGOs - in the response to the epidemic?'). This discussion addresses the questions which frames of HIV have been most effective in Russia and why. The discussion also investigates to what extent the identified HIV frames have created opportunities or obstacles for Russian NGOs and how framing processes have shaped the response to HIV in Russia.

Based on Entman's framing model, four main frames can be identified in the discourses on HIV/AIDS in Russia: (1) HIV as a medical issue, (2) HIV as a security threat, (3) HIV as a moral issue, and (4) HIV as a human rights issue. These four frames differ from each other in the way they define the problem, interpret the causal relations, attribute moral responsibility and develop treatment recommendations (see the four dimensions in Entman's framing model). ${ }^{75}$ The four frames have existed parallel to each other and partly overlap in public discourses. The moral framing of HIV, for instance, partly feeds into the security framing, as both frames identify HIV as an external threat that endangers Russian society by undermining its 'traditional values'. The medical frame is sometimes linked to the framing of HIV as a human rights issue, as medical information is applied to substantiate human rights claims, e.g. in defending the rights of groups which, due to medical and social reasons, are particularly vulnerable to HIV.

Although the four frames have coexisted alongside each other and are used by different policy actors, the framing of HIV as a moral issue has become more dominant in recent years, which can partly be attributed to the increasing influence of the Russian Orthodox Church in domestic politics. ${ }^{76}$ When we take a closer look at the four frames and their proliferation in the Russian public discourse on HIV, we can conclude that the framing of HIV as a medical issue is strong in terms of problem formulation and causal explanation, but weak in terms of moral evaluation and treatment recommendations. In the communications by the regional AIDs Centers, which are the main state institutions responsible for epidemiological monitoring, prevention and treatment in Russia, the information on medical issues clearly prevails. However, the AIDS Centers seldom discuss HIV in a broader societal context or reach out to the general public. The same holds true for self-help organizations or governmentorganized NGOs that often operate on the premises of the regional AIDS Centers. The medicalization of the issues means that the discourse remains a niche topic. Mainstream Russia media provide information on HIV on World AIDS

75 Entman, "Framing: Toward Clarification of a Fractured Paradigm", 1993.

76 Wilkinson, "Putting 'Traditional Values' Into Practice”, 368. 
Day in December and Aids Memorial Day in May. On these occasions, medical experts of the Russian AIDS Center share the newest epidemiological information and give advice for voluntary testing and prevention. Apart from these days, little public information on HIV is provided. One can conclude that the medical frame has not much influence on the public debate about HIV/AIDS in Russia.

The framing of HIV as a security threat had been influential in alarming decision-makers and calling for action. Putin's speech to the National Security Council in April 2006 marked an important policy shift, as it clearly indicated the recognition of the problem of HIV and the political will to tackle the epidemic in Russia. For civil society actors the securitization of the issue opened up opportunities for participating in HIV prevention programs and cooperating with state institutions. In his speech, president Putin emphasized the need for collaboration with NG Os: 'We need to get the business community, political parties and civil society more actively involved in this information and prevention work. ${ }^{77}$ However, after an initial phase of increased awareness, securitization did not have much effect on the response to the epidemic. On the contrary, the increasing tensions between Russia and the West after 2008 led to a decline of evidence-based prevention programs endorsed by international organization, and a growing emphasis on approaches based on the promotion of so-called 'traditional values'.

The framing of HIV as an issue of morality is strong in terms of moral judgement and treatment recommendations. It can be regarded as the most dominant framing in the Russian discourse on HIV. During the past decade the moral frame has gained currency, as conservative voices have become more vocal in debates on sexuality in Russia. The moral frame links the response to HIV/AIDS to so-called 'traditional values'. The epidemic is viewed as the result of harmful influences from the West, which Russia needs to fight in order to overcome the threat of HIV. Interestingly, the notion of 'traditional values' is frequently used in discourses on sexuality in Russia, but never clearly defined. ${ }^{78}$ The discourse on 'traditional values' emphasizes family values, heterosexuality (described as 'traditional sexual orientation') and faithfulness, sexual abstinence before marriage, and healthy lifestyle behavior such as abstinence

77 Vladimir Putin, "Opening Remarks at State Council Presidium Meeting on Urgent Measures to Combat the Spread of HIV-AIDS in the Russian Federation", 21 April 2006, http:// kremlin.ru/events/president/transcripts/23547, accessed 15 June 2006.

78 Paul Chaney, "Civil Society, 'Traditional Values' and LG BT Resistance to Heteronormative Rights Hegemony: Analysis of the Un Universal Periodic Review in the Russian Federation", Europe-Asia Studies 70, no 4 (2018): 638-665. 
from alcohol, cigarettes and drugs which are depicted as immoral behavior induced by Western popular culture. Important in the discourse on 'traditional values' is the clear division between Russia and the West, which is constructed as morally inferior. Some researchers even speak of a 'sexual sovereignty', which Russia seeks to defend in international politics. ${ }^{79}$ The moral frame has a decisive impact on HIV policies in Russia, as it has undermined the legitimacy of so-called evidence-based prevention programs which are endorsed by UNAIDS and other international organizations, and instead called for a response to HIV that is specific to Russia and different from the West.

The moral frame also weakened the role of NGOs in the response to the epidemic. Russian NGOS face criticism and opposition against specific interventions from a number of political and societal actors, particularly if they have adopted so-called evidence-based prevention programs or receive funding from international donors. Parents' organizations as well as the Russian Orthodox Church have repeatedly joined forces against the introduction of HIV/AIDS prevention programs in Russia, thus discrediting foreign-funded NGOs by using anti-Western sentiments. ${ }^{80}$ In 2008, the Russian Parents' Assembly, for instance, appealed to the Russian government to fully ban AIDSservice NGOs in Russia, as they were allegedly acting in the interests of foreign powers and aiming to aggravate Russia's demographic crisis. ${ }^{81}$ As of today, the Russian Orthodox Church continues to prevent the introduction of sex education into the curriculum of Russian secondary schools, thereby hampering the effort to prevent HIV/AIDS among young people. Furthermore, widespread opposition to harm reduction strategies on the part of Russian decision-makers has impeded HIV/AIDS prevention among injecting drug users, who are particularly vulnerable to HIV.

79 Aleksandr Baunov, "Seksual'nyj suverenitet rodiny kak novaya vneshnyaya politika Rossii," Slon, 21 August 2013, https://republic.ru/world/novaya_vneshnyaya_politika-980570 .xhtml, accessed 1 October 2018.

8o Russian sociologist Igor Kon wrote several articles about the changing sexual norms and practices in Soviet and post-Soviet Russia. He explained the resistance of the Russian Orthodox Church against the introduction of sex education programmes as a form of cultural resistance against norms that are perceived as Western and thus anti-Russian. Kon's works are published in Russian and English: Igor S. Kon, Seksual'naia kul'tura v Rossii: Klubnichka na berezke, 2e izd., pererab. i dop. (Moskva, Airis-press, 2005); Igor S. Kon, The Sexual Revolution in Russia. From the Age of the Czars to Today (New York, The Free Press, 1995).

81 All-Russian Parent's Assembly: "Open letter of the parents of Russia", available at <http:// oodvrs.ru/article/index.php?id_page=21\&id_articles=329>, accessed on 22 June 2018. 
The framing of HIV as a human rights issue is strong as it offers a link to international organizations and enables mobilization and empowerment of vulnerable groups. The human rights frame connects the issue of HIV/AIDS to a broader discourse on social and political rights. UNAIDS emphasized that Russia had one of the fastest-growing HIV/AIDS epidemics in the world and called for stronger political leadership in the response to the epidemic. ${ }^{82}$ Moreover, the scenarios from the World Bank, the UNDP and the ILO that predicted a steep decrease of Russia's economy as a consequence of the HIV/AIDS epidemic gained the attention of Russian decision makers and served as a wake-up call. ${ }^{83}$ Beyond that, international organizations stressed the need to include civil society in the response to the epidemic, which strengthened the position of AIDS-service NGOs in Russia.

The involvement of civil society constitutes a principle in the international HIV/AIDS regime, as demonstrated in the UNGass Declaration of Commitment on HIV/AIDS, according to which the full involvement and participation of civil society actors in the design, planning, implementation and evaluation of programs is crucial to the development of effective responses to the HIV/AIDS epidemic' ${ }^{84}$ UNAIDS supports the active participation of NGOS as it believes that they can fulfil a bridge function to the most vulnerable and hard-to-reach population, and thereby guarantee that HIV/AIDS prevention becomes rooted in local communities. ${ }^{85}$ In the view of UNAIDS, civil society encompasses both international NGOs (mostly focusing on the nexus of human rights and HIV/AIDS) and local community organizations which represent people affected by the epidemic.

In the international HIV/AIDS regime, the framing of HIV as a human rights issue has become very influential, as human rights are thought 'to trump other objectives' ${ }^{\prime 6}$ The participation of people living with HIV and local communities has been a central element in the work of international organizations and

82 UNAIDS, 'AIDS epidemic update: December 2002', http://www.who.int/hiv/pub/epidemi ology/epi2002/en/, accessed 12 July 1009 .

83 Shombi Sharp, "The Economic Impact of HIV/AIDs in Russia: Current Trends and Perspectives", in: Judyth L.Twigg ed., HIV/AIDS in Russia and Eurasia, Vol. 1, (New York: Palgrave, 2006): 77-102.

84 "Declaration of Commitment on HIV/AIDs", United Nations General Assembly Special Session on HIV/AIDS, 25-27 June 2001, http://data.unaids.org/publications/irc-pubo3/ aidsdeclaration_en.pdf.

85 unAIDs, “Civil Society: Why Engage?", http://www.unaids.org/en/Partnerships/Civil+ society/why_engage.asp, accessed 12 July 2018.

86 Joshua W. Busby and Ethan B. Kapstein, "Framing Global Health as Human Rights: Learning from the Case of HIV/AIDs", Global Health Governance 10, no 3 (2016): 24-40. 
is emphasized in all international declarations and agreements regarding the response to the global epidemic. The importance of the rights-based approach is deeply rooted in the historical development of HIV/AIDS politics. In the first years of the epidemic community groups and advocacy organizations mainly shaped the response to HIV/AIDS. In many countries, the framing of HIV as a human rights issue served as a powerful tool for identity building and empowerment. It has united people affected by the epidemic and forced international organizations to take their needs into account. In recent years, the 'right to prevention and life-saving treatment' has become a key concern for both nongovernmental and public organizations. ${ }^{87}$

In Russia, however, the framing of HIV as a human rights issue has not been successful, as government actors have turned away from the recommendations of international organizations. The discourse on 'traditional values' has been constructed as an alternative in opposition to the international language of human rights, which is described as alien and harmful for Russia. This opposition is visible in many policy fields, including the field of LGBT rights, where 'traditional values' are emphasized at the expense of international human rights norms. ${ }^{88}$

In the response to HIV/AIDS the emphasis on 'traditional values' has many practical implications. Prevention programs that are described as Western approaches, such as harm reduction, condom promotion and sex education programs are opposed by Russian decision makers. This means that important elements for effectively confronting HIV in Russia are missing, with negative consequences for the effectiveness of the Russian response to the epidemic. The opposition against evidence-based prevention programs has also brought NGOs with a rights-based approach into growing opposition to the Russian state. Even those organizations that frame their work as nonpolitical face difficulties, as their work is understood to harmful for Russia. The framing processes that have led to an emphasis on HIV as a moral issue have therefore weakened the mobilization potential for many AIDS-service NGOs in Russia.

Conclusions: How Does Framing Affect the Response to HIV?

This article has analyzed the framing of HIV in Russia. It argued that frames are very powerful tools that shape the way certain issues are perceived and

87 B.M. Meier, K.N. Brugh, and Y. Halima, "Conceptualizing a Human Right to Prevention in Global HIv/AIDs Policy”, Public Health Ethics 5, no. 3 (2012): 263-282.

88

Wilkinson "Putting 'Traditional Values' Into Practice”, 365. 
discussed in societal discourses. Civil society actors both participate in the construction of frames and are influenced by them. Their mobilization potential depends on the way they are able to connect with dominant frames. Based on the frameworks by Entman as well as Benford and Snow, the article showed that different and opposed framings of the epidemic have existed next to each other. The framing of HIV as a moral issue has become dominant in the discourse on HIV in Russia over the past years. The moral framing is promoted by the Russian Orthodox Church and by conservative groups such as parents' organizations. The moral framing emphasizes 'traditional values' and undermines evidence prevention programs, which are portrayed as a harmful influence from the West.

The moral framing increases the conflict between the Russian government and international organizations on the formulation of HIV prevention and treatment programs in Russia. The moral framing also means that the position of AIDS-service NGOS is weakened. That especially holds true for organizations that provide prevention among vulnerable groups such as injecting drug users. At present, the Russian government does not support prevention programs among vulnerable groups and does not provide funding. With the decline of foreign funding and the growing resistance against foreign-funded activities, however, many NGO prevention programs for vulnerable groups have been forced to close their doors.

The moral frame also affects the position of AIDS-service NGOs in Russian society. Due to increasing stigma and discrimination, NGOs find it difficult to create support from Russian society at large. For many Russians, the epidemic is linked to immoral behavior such as drug use or a promiscuous life style. As a result, large parts of Russian society are not prepared to support HIV/AIDS prevention programs. This makes it for NGOs very difficult to reach out to society and create societal support for their work.

The dominant moral framing of HIV also influences the orientation of NGOS in the response to the epidemic in Russia. The best chances to use their mobilization potential lies with those NGOS that can relate their work to the dominant discourse of creating a healthy environment for the young generation. Framed as healthy lifestyle promotion, HIV prevention programs for young people can build upon widespread understanding in Russian society and enjoy increasing popularity and support from state officials. HIV interventions for vulnerable groups, by contrast, are much more difficult to sell to the Russian public, as these programs are not generally accepted in Russia and face opposition from decision makers. NG Os working with vulnerable groups therefore tend not to promote their work in the media and abstain from the public discourse. Their mobilization potential can thus be regarded as significantly 
lower than those NGOs that provide more visible and widely acceptable primary HIV/AIDS prevention.

\section{Primary Sources}

Interviews with representatives of AIDS-service NGOs in Russia were conducted in 2008-2009 and 2017-2018.

\section{References}

All-Russian Parent's Assembly, "Open letter of the parents of Russia", available at http://oodvrs.ru/article/index.php?id_page=21\&id_articles=329, accessed on 17 July 2018.

Baunov, Aleksandr, "Seksual'nyj suverenitet rodiny kak novaia vneshniaia politika Rossii," Slon, 21 August, https://republic.ru/world/novaya_vneshnyaya_politika-980570 .xhtml, accessed 1 October 2018.

Benford, Robert D. and Snow, David A. (200o), "Framing Processes and Social Movements: An Overview and Assessment." Annual Review of Sociology 26, no 1 (2000): 611-639.

Bobrik, Alexey and Judyth L. Twigg. "HIV/AIDs in Russia." in Judyth L. Twigg ed., HIV/AIDS in Russia and Eurasia (New York: Palgrave Macmillan, 2006): 1-40.

Bogdanova, Elena, Linda Cook, and Meri Kulmala, "The Carrot or the Stick? Constraints and Opportunities of Russia's cso Policy", Europe-Asia Studies 70, no 4 (2018): 501-513.

Brown, Hannah, "Russia's Blossoming Civil Society Holds the Key to HIV", The Lancet 368, no. 9534 (2006): 37-440.

Busby, Joshua W. and Ethan B. Kapstein, "Framing Global Health as Human Rights: Learning from the Case of HIV/AIDS," Global Health Governance 10, no 3 (2016): 24-40.

Chaney, Paul, “Civil Society, 'Traditional Values' and LGBT Resistance to Heteronormative Rights Hegemony: Analysis of the UN Universal Periodic Review in the Russian Federation", Europe-Asia Studies 70, no 4 (2018): 638-665.

Cook, Linda J. and Elena Vinogradova, "NGOs and Social Policy-Making in Russia's Regions" Problems of Post-Communism 53, no. 5 (2006): 28-41.

Crotty, Jo, "Making a Difference? NGos and Civil Society Development in Russia", Europe-Asia Studies 61, no 1 (2009): 85-108.

Declaration of Commitment on HIV/AIDS, United Nations General Assembly Special Session on HIV/AIDS, 25-27 June 2001, available at http://data.unaids.org/publica tions/irc-pubo3/aidsdeclaration_en.pdf, accessed 7 July 2018. 
Entman, Robert M., "Framing: Toward clarification of a fractured paradigm", Journal of Communication 43, no. 4 (1993): 51-58.

Global Fund to Fight HIV/AIDs, Tuberculosis and Malaria, available at http://www .theglobalfund.org/, accessed 17 July 2018.

Goffman, Erving, Frame Analysis: An Essay on the Organisation of Experience (New York: Harper \& Row, 1974).

Gorobets, A., "Promotion of sports, physical activity, and a healthy lifestyle in Russia", The Lancet, 385, no 9986 (2015): 2459.

Henry, Laura A., "Shaping Social Activism in Post-Soviet Russia: Leadership, Organizational Diversity, and Innovation", Post-Soviet Affairs 22, no. 2 (2006): 99-124.

Joachim, Jutta, "Framing Issues and Seizing Opportunities: The UN, NGOs, and Women's Rights", International Studies Quarterly 47 (2003): 247-274.

Keck, Margaret K. and Kathryn Sikkink, Activists beyond Borders, Advocacy Networks in International Politics (Ithaca, Cornell University Press, 1998).

Kontseptsiia uchastiia Russkoi Pravoslavnoi Tserkvi v bor'be s rasprostraneniem vich/sPIDa i rabote s liud'mi, zhivushchimi s vich/sPIDom, Russkaia Pravoslavnaia Tserkov, 24 June 2005.

Meier, B.M., Brugh, K.N. and Halima, Y., "Conceptualizing a Human Right to Prevention in Global HIv/AIDs Policy”, Public Health Ethics 5, no 3 (2012): 263-282.

Morrison, J. Stephen and Jennifer Kates (2006). The G-8, Russia's Presidency, and HIV/ AIDS in Eurasia. A Report of the CSIS Task Force on HIV/AIDS 70, no 4 (2018)in collaboration with the Kaiser Family Foundation (Washington, D.c.: Kaiser Family Foundation), https://kaiserfamilyfoundation.files.wordpress.com/2013/04/csisg 8russpres.pdf, accessed 22 June 2018.

Positive Wave, available at https://pozvolna.ru/allrights/humanrights/2/, accessed 13 July 2018.

Putin, Vladimir, "Opening Remarks at State Council Presidium Meeting on Urgent Measures to Combat the Spread of HIV-AIDs in the Russian Federation", 21 April 2006, http://kremlin.ru/events/president/transcripts/23547, accessed 15June 2018.

Russian Health Care Foundation, http://www.srhiv.mednet.ru/open/fund.php?\& language $=$ eng, accessed at 17 June 2018.

Russian Security Council, "Strategy of National Security of the Russian Federation until 2020, confirmed by Decree of the President of the Russian Federation No 537 of 12 May 2009" as published in Krasnaya Zvezda, weekly edition 20-26 May 2009, accessed 15 June 2018.

Salamon, Lester M. and S. Wojciech Sokolowski, "Beyond Nonprofits: Re-conceptualizing the Third Sector", Voluntas. International Journal of Voluntary \& Nonprofit Organizations 27, no 4 (2016): 1515-1545.

Sharp, Shombi, "The Economic Impact of HIV/AIDs in Russia: Current Trends and Perspectives", in Twigg, Judyth L., ed. HIV/AIDS in Russia and Eurasia, Vol. 1 (New York: Palgrave, 2006), 77-102. 
Skokova, Yulia, Pape, Ulla and Irina Krasnopolskaya, "The Non-profit Sector in Today's Russia: Between Confrontation and Co-optation", Europe-Asia Studies 70, no 4 (2018): 531-563.

Snow, David A. and Robert D., Benford, "Ideology, frame resonance, and participant mobilization", International social movement research 1, no 1 (1988): 197-217.

Snow, David A. and Robert D., Benford "Master frames and cycles of protest", in Morris, A.D. and Mueller, C.M. (eds.) (1992). Frontiers in Social Movement Theory (New Haven, CT: Yale University Press, 1992), 133-155.

The Global Fund to Fight AIDs, Tuberculosis and Malaria, available at https://www .theglobalfund.org/en/, accessed 5 July 2018.

Tsetsura, Katerina "Challenges in framing women's rights as human rights at the domestic level: A case study of NGOs in the post-Soviet countries", Public Relations Review 39, no 4 (2013): 406-416.

UnAIDs, 'Civil society: why engage?', http://www.unaids.org/en/Partnerships/Civil+ society/why_engage.asp, accessed 5 July 2018.

UNAIDS, Topic: Human rights, http://www.unaids.org/en/topic/rights, accessed 12 June 2017 .

Wilkinson, Cai, "Putting 'Traditional Values' Into Practice: The Rise and Contestation of Anti-Homopropaganda Laws in Russia”, Journal of Human Rights 13, no 3 (2014): 363-379.

Zigon, Jarrett, "Morality and HIV/AIDs: A Comparison of Russian Orthodox Church and Secular NGo Approaches," Religion, State \& Society 37, no. 3 (2009): 311-325. 